\title{
Prediction of Strength Properties of Concrete Containing Calcined Black Cotton Soil Using Response Surface Methodology
}

\author{
Aliyu Abubakar*, Udofia Ruth Idongesit, Claudius Konitufe, Abbagana Mohammed \\ Department of Civil Engineering, Abubakar Tafawa Balewa University, Bauchi, Nigeria \\ Email address: \\ ea.aliyu@gmail.com (A. Abubakar), iruthudofia@gmail.com (U. R. Idongesit), claudiuskonitufe@gmail.com (C. Konitufe), \\ abbaganam@gmail.com (A. Mohammed) \\ ${ }^{*}$ Corresponding author
}

\section{To cite this article:}

Aliyu Abubakar, Udofia Ruth Idongesit, Claudius Konitufe, Abbagana Mohammed. Prediction of Strength Properties of Concrete Containing Calcined Black Cotton Soil Using Response Surface Methodology. American Journal of Construction and Building Materials.

Vol. 5, No. 2, 2020, pp. 17-25. doi: 10.11648/j.ajmsp.20200502.11

Received: July 16, 2020; Accepted: August 4, 2020; Published: December 16, 2020

\begin{abstract}
This research predicts the strength properties of concrete containing Calcined Black Cotton Soil (CBCS) using response surface methodology. Cement production requires large amount of energy and emits greenhouse gases that have negative impact on the environment. Utilization of CBCS as cement replacement in concrete will reduce these negative impact. Experimental plan was designed using response surface method in Design Expert software to predict compressive strength, density and water absorption of concrete containing CBCS. The CBCS was varied from 5 to $20 \%$ while the curing period was varied and 7 to 28 days. Face-centered central composite design method of response surface was used. The design consists of two design factors at three levels (coded as $-1,0,+1$ ) each. The factors are the curing period, and the CBCS contents. The results showed that $\mathrm{CBCS}$ is a pozzolana. CBCS increases durability of concrete by decreasing its water absorption. All the response surface models developed for the water absorption, density and compressive strength showed very good relationship between the predictors and the responses with coefficients of determination, $\mathrm{R}^{2}>0.94$ and $\mathrm{p}$-values $<0.05$.
\end{abstract}

Keywords: Calcined Black Cotton Soil, Compressive Strength, Concrete, Density, Response Surface Methodology, Water Absorption

\section{Introduction}

Concrete is one of the most widely used construction material in the world due to availability of its constituents materials. Its major constituent materials are cement, gravel, sand and water. More than 20 billion tons of concrete is produced annually, which is the highest among all composite materials [1].

Cement represents $10-15 \%$ of total weight of concrete with annual production of about 2.8 billion tons worldwide [2]. Manufacture of cement is highly energy and carbon IV oxide $\left(\mathrm{CO}_{2}\right)$ emission intensive due to the extreme heat required during its production. The $\mathrm{CO}_{2}$ emission has negative impact on the environment. Also, the extraction of raw materials for cement production damages the environment [3].

Under the strong demand for modern, economically viable and environmentally friendly materials, researchers have focused on the use of Supplementary cementitious materials (SCMs) as partial replacement of cement in concrete and mortar production. SCMs have been used in concrete production which yielded improvement in strength and durability of the concrete. These materials exhibit very good pozolanic activity due to high content of silicate and alumina. When used in right proportion, SCMs can improve the fresh and hardened properties of concrete [2]. SCMs save a significant amount of cement and give specific properties to cementitious products that help to meet the requirement of mordern construction [4].

Black cotton soils (BCSs) are found in the North Eastern part of Nigeria where they occupy an estimated area of $104,000 \mathrm{~km}^{2}$. They are dark colored expansive clays rich in montmorillonite clay minerals. BCSs are known to be 
problematic because of the presence of this montmorillonite, which is highly responsible for the shrinkage-swell behavior of the soil depending on the available moisture in the soil. Also, montmorillonite is the root cause of many problems such as pavement failure and excessive settlement associated with the BCSs [5].

Response surface methodology (RSM) is a collection of mathematical and statistical techniques for empirical model building. The major objective of RSM is to optimize a response (output variable) which is influenced by several independent variables (input variables). Results obtained from series of experimental tests, called runs, are used as the input variables in order to identify the reasons for changes in the output response. Empirical models are developed to predict the response under similar experimental conditions [6].

This research is aimed at predicting the strength properties of concrete containing $\mathrm{CBCS}$ as partial replacement of ordinary Portland cement using response surface methodology. Utilization of CBCS as partial replacement of cement in concrete production will reduce the cement content in the concrete and thereby reduces the embodied $\mathrm{CO}_{2}$ emission and increases environmental friendliness of the concrete.

The calcination (thermal treatment) temperatures suitable to produce a good cement replacement material have been reported to be between $500^{\circ} \mathrm{C}$ and $900^{\circ} \mathrm{C}$ depending on the nature and type of clay. Calcination of natural pozzolana containing clay at this temperature range increases performance of the pozzolana. The thermal treatment destroys the crystal structure of the clay minerals and transforms it to a very reactive amorphous structure [7]. The advantage of using CBCS as pozzolan in concrete compared with other pozzolanic materials is the ease of access of the BCS in most parts of the world at low price. Grinding can also be advantageous by breaking up particle agglomerates and exposing additional surface area.

\section{Materials and Methods}

\subsection{Materials}

The various material used in the investigation are; ordinary Portland cement, fine aggregate, coarse aggregate, CBCS and water.

\subsubsection{Cement}

Ashaka brand of Portland cement (Grade 32.5) was used throughout the investigation. The cement was obtained from a local dealer and stored in a cool dry location. The cement conforms to EN 197:1 [8] specification.

\subsubsection{Fine Aggregate}

The fine aggregate (sand) used was obtained from a stream in Bauchi. Sand particles not larger than $4.75 \mathrm{~mm}$ were used in the experiments. The specific gravity of the sand was found to be 2.65. The sand falls within zone 2 after conducting the particle size distribution test. The tests were conducted in accordance with BS EN 1097:6, BS 812:2 and
BS EN 933:1 specifications respectively [9, 10, 11].

\subsubsection{Coarse Aggregate}

The coarse aggregate used was normal weight crushed aggregate of igneous rock origin with particle sizes larger than $4.75 \mathrm{~mm}$ but less than $20 \mathrm{~mm}$. It was obtained from a quarry site in Bauchi. The aggregate has specific gravity of 2.69, aggregate crushing value of $26.7 \%$ and aggregate impact value of $12.9 \%$. The tests were conducted in accordance with BS EN 1097:6, BS 812:2, BS 812:110 and BS EN 933:1 specifications respectively $[9,10,11,12]$.

\subsubsection{Calcined Black Cotton Soil}

The BCS was collected from Baure town in Yemaltu-Deba Local Government area of Gombe State in the North Eastern part of Nigeria. The village is located on Latitude $10^{\circ} 13^{\prime} \mathrm{N}$ and Longitude $11^{\circ} 23^{\prime}$. The BCS is dark gray in colour and is called 'Kasan Kalari' in Hausa. The soil was calcined in a kiln using temperature range of $600^{\circ} \mathrm{C}-1000^{\circ} \mathrm{C}$. The calcined soil was ground and sieved using 75 micrometer sieve. The specific gravity and $\mathrm{pH}$ for the $\mathrm{CBCS}$ was found to be 2.78 and 7.6 respectively. The oxides composition of the CBCS was determined using X-ray fluorescence (XRF) test in accordance with American Society for Testing Materials ASTM C311-11b and ASTM C618 specifications $[13,14]$. The test was conducted at Ashaka Cement Factory, Gombe State.

\subsection{Methods}

\subsubsection{Experimental Design}

A mix proportion of 1:2:3 and water-to-cement ratio of 0.5 were adopted throughout the experiment. The experiment was designed using response surface method in Design Expert software. The CBCS was varied from 5 to $20 \%$ while the curing period was varied and 7 to 28 days. Face-centered central composite design method of response surface was used. The design consists of two design factors at three levels (coded as $-1,0,+1$ ) each. The factors are the curing period, and the CBCS contents.

The samples were produced and cured in accordance with BS EN 12390:1 and BS EN 12390:2 specifications [15, 16]. Concrete cubes of size $100 \mathrm{~mm} \times 100 \mathrm{~mm} \times 100 \mathrm{~mm}$ were cast and cured by water immersion for 7,14 and 28 days respectively before testing.

\subsubsection{Specimens Testing}

The strength activity index test was conducted on $50 \mathrm{~mm} x$ $50 \mathrm{~mm}$ x $50 \mathrm{~mm}$ mortar specimens containing 0 and $20 \%$ CBCS replacing cement by weight. Compressive strength of the mortar specimens were determined after curing for 7 and 28 days. The test was conducted in accordance with ASTM C311-11b specifications [13].

The workability of the fresh concrete was determined using slump test in accordance with BS EN 12350:2 specifications [17]. The test was conducted on the specimens containing 0, 5, 10, 15 and $20 \%$ CBCS.

Compressive strength test was conducted on hardened concrete cubes. Three (3) cubes were tested for each curing 
period and levels of cement replacement in accordance with BS EN 12390:3 and BS EN 12390:4 specifications [18, 19].

The saturated density of the hardened concrete cubes prepared for compressive strength test was calculated as per BS EN 12390:7. The water absorption was determined on the concrete cubes prepared for compressive strength test. The test was carried out in accordance with BS 1881:122 specification $[20,21]$.

\section{Results and Discussions}

\subsection{Oxides composition of $\mathrm{CBCS}$}

The oxides compositions of CBCS are presented in Table 1.

Table 1. Oxide Composition of Calcined Black Cotton Soil.

\begin{tabular}{|c|c|}
\hline Oxide & Composition (\%) \\
\hline $\mathrm{SiO}_{2}$ & 46.294 \\
\hline $\mathrm{Al}_{2} \mathrm{O}_{3}$ & 12.123 \\
\hline $\mathrm{Fe}_{2} \mathrm{O}_{3}$ & 5.861 \\
\hline $\mathrm{CaO}$ & 12.950 \\
\hline $\mathrm{MgO}$ & 0.921 \\
\hline $\mathrm{SO}_{3}$ & 2.215 \\
\hline $\mathrm{K}_{2} \mathrm{O}$ & 0.737 \\
\hline $\mathrm{Na}_{2} \mathrm{O}$ & 0.153 \\
\hline $\mathrm{P}_{2} \mathrm{O}_{5}$ & 0.064 \\
\hline $\mathrm{Mn}_{2} \mathrm{O}_{3}$ & 0.139 \\
\hline $\mathrm{TiO}_{2}$ & 0.919 \\
\hline LSF & 8.766 \\
\hline Silica Ratio & 2.574 \\
\hline Aluminum Ratio & 2.068 \\
\hline Calcium Carbonate & 23.114 \\
\hline Ignition loss (\%) & 11.177 \\
\hline Sum Of Conc. & 82.376 \\
\hline $\mathrm{C}_{3} \mathrm{~S}$ & -598.358 \\
\hline
\end{tabular}

\subsection{Strength Activity Index (SAI)}

The Strength Activity index for batches of the test cube produced in accordance with ASTM C311-11b [13] as shown in figure 1 . The results obtained is presented in table 2 .

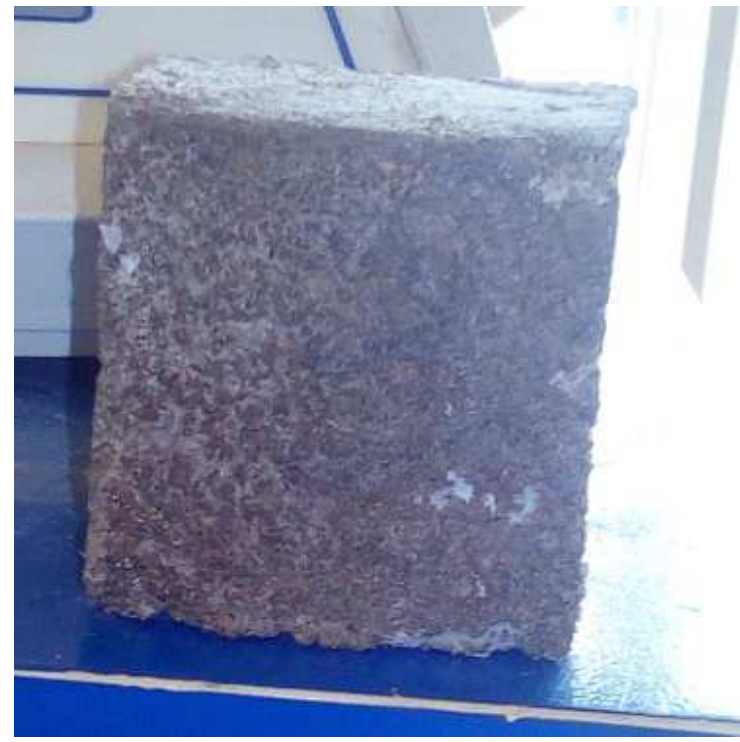

Figure 1. Sample for Strength Activity Index test.
Table 2. Strength Activity Index (SAI).

\begin{tabular}{lllll}
\hline $\begin{array}{l}\text { Curing period } \\
\text { (days) }\end{array}$ & $\begin{array}{l}\text { Cement } \\
(\%)\end{array}$ & $\begin{array}{l}\text { CBCS } \\
(\%)\end{array}$ & $\begin{array}{l}\text { Average Comp. } \\
\text { str. }\left(\mathbf{N} / \mathbf{m m}^{\mathbf{2}}\right)\end{array}$ & $\begin{array}{l}\text { SAI } \\
(\%)\end{array}$ \\
\hline \multirow{2}{*}{14} & 100 & 0 & 1.91 & 69.6 \\
& 80 & 20 & 1.33 & \\
28 & 100 & 0 & 2.18 & 86.7 \\
\hline
\end{tabular}

\subsection{Workability of Fresh Concrete}

Workability of the fresh concrete was measured using slump test (figure 2). The test was conducted on concrete containing $0,5,10,15$ and $20 \% \mathrm{CBCS}$ in accordance with BS EN 12350: 2 [17]. The results obtained are presented in the figure 3 which show that addition of CBCS decreases the workability of the concrete. The workability decreased from $40 \mathrm{~mm}$ at $0 \%$ CBCS content to $22 \mathrm{~mm}$ at $20 \% \mathrm{CBCS}$ content. This is $29 \%$ drop in workability of the concrete when compared to the control. Therefore increase in CBCS contents affect the workability of the concrete.

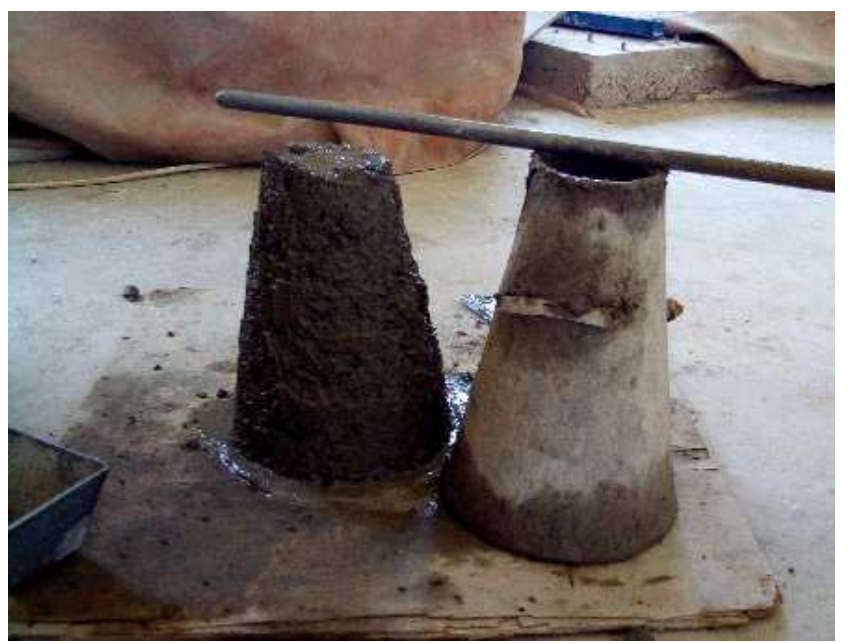

Figure 2. Measurement of workability of concrete.

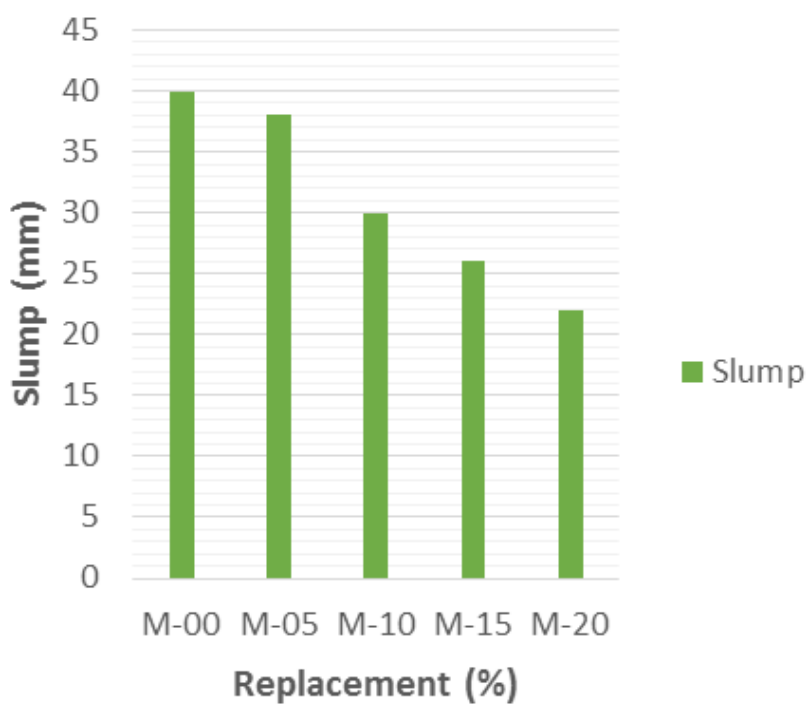

Figure 3. Workability of concrete against CBCS contents. 


\subsection{Water Absorption}

The test was conducted in accordance with BS 1881 part 122 [21]. Figure 4a shows the contour plot of curing period (CP) against the CBCS contents while figure $4 \mathrm{~b}$ shows the surface plot. From figure $4 \mathrm{~b}$, the water absorption increased with increase in $\mathrm{CP}$. Also the water absorption increases with increase in CBCS contents up to $10 \%$ replacement. Beyond $10 \%$ CBCS contents the water absorption decreases, this is because of high volume of CBCS (due to its lower density than cement) which blocked the pores in the concrete and durability of concrete increases with decrease in its water absorption.
Design-Expert@ Software

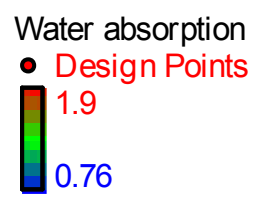

$\mathrm{X} 1=\mathrm{A}: \mathrm{CBCS}$

$\mathrm{X} 2=\mathrm{B}: \mathrm{CP}$

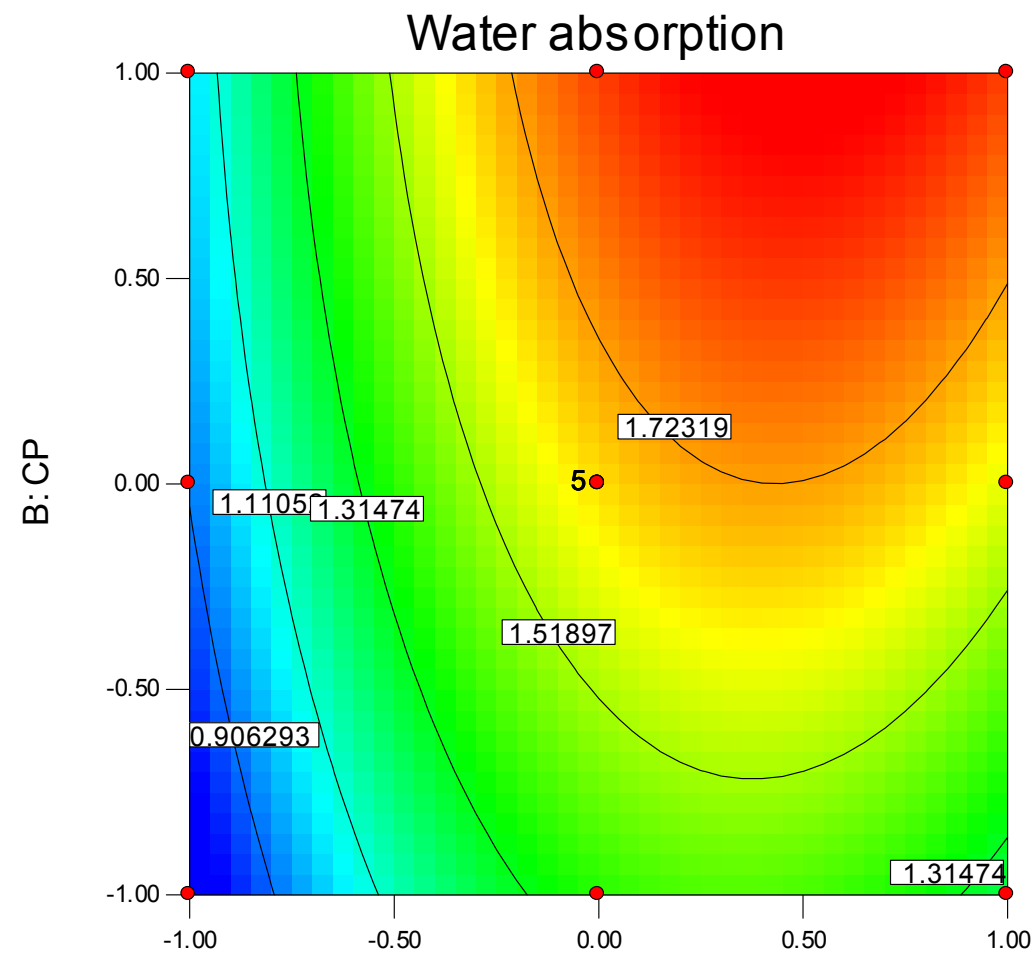

A: CBCS

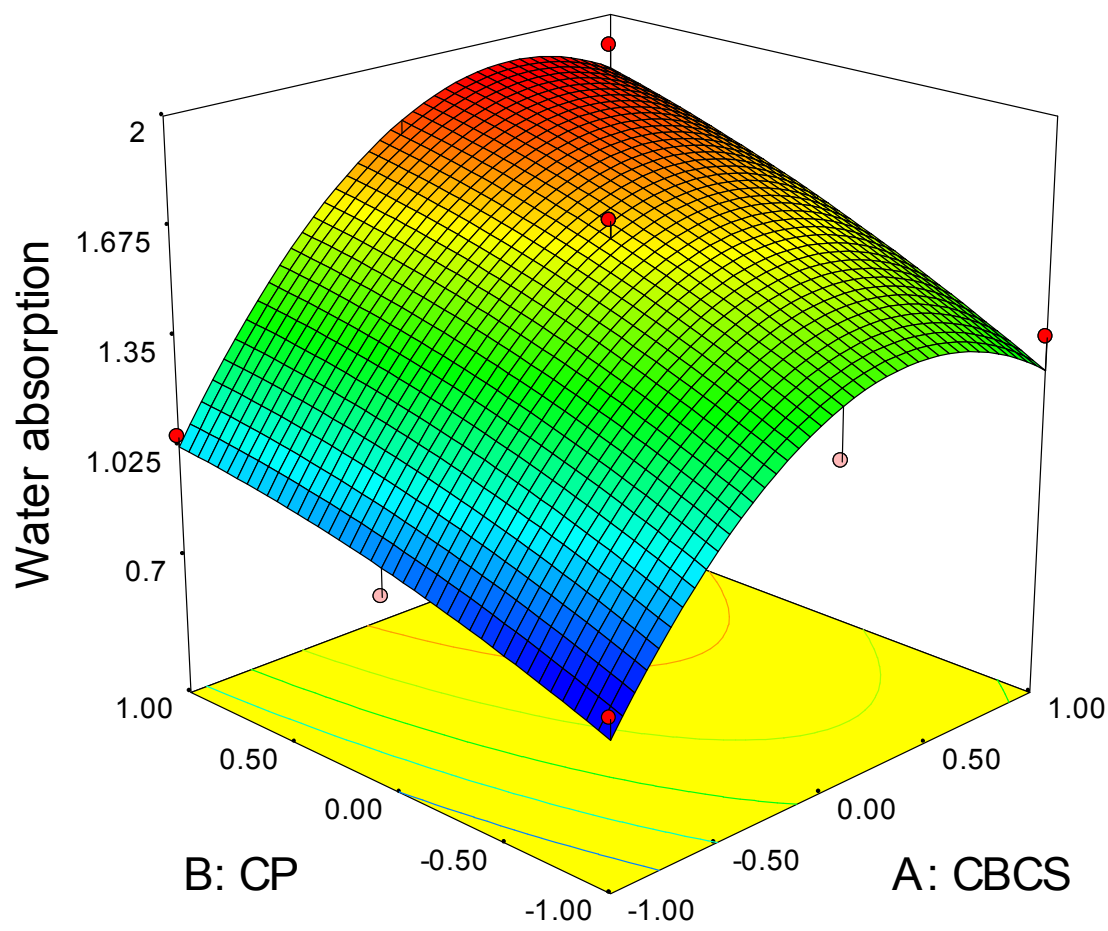

Figure 4. $(a \& b)$ Variation of Water Absorption with CBCS and Curing Period. 
Table 3 shows results ANOVA of water absorption of concrete containing various CBCS contents. The Model Fvalue of 22.09 implies the model is significant. The P-values less than 0.05 indicate model terms are significant. In this case $\mathrm{A}, \mathrm{B}, \mathrm{A}^{2}$ are significant model terms. The coefficient of determination, $R^{2}$, is 0.9404 while the adjusted $R^{2}$ is 0.8978 which indicate that there is very good relationship between the predictors (CBCS and CP) and the response (Water absorption). The model equations are presented in equations (1) \& (2).

The model equation in terms of coded factors is presented in equation (1):

$$
\text { Water absorption }=+1.65+0.34 * \mathrm{~A}+0.22 * \mathrm{~B}+0.06 * \mathrm{~A} * \mathrm{~B}-0.39 * \mathrm{~A}^{2}-0.049 * \mathrm{~B}^{2}
$$

The model equation in terms of actual factors is presented in equation (2):

$$
\text { Water absorption }=+1.64966+0.34 * \mathrm{CBCS}+0.225 * \mathrm{CP}+0.06 * \mathrm{CBCS}^{*} \mathrm{CP}-0.39379 * \mathrm{CBCS}^{2}-0.048793 * \mathrm{CP}^{2}
$$

Table 3. ANOVA results for water absorption.

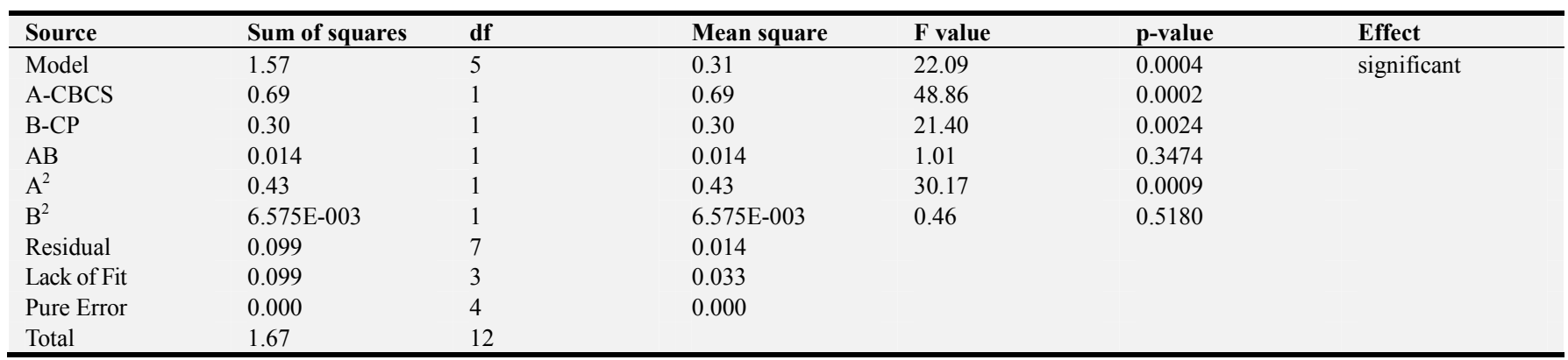

\subsection{Density}

The test was conducted on hardened concrete containing CBCS in accordance with BS EN12390:7 [20]. Figure 5a shows contour plot of $\mathrm{CP}$ against $\mathrm{CBCS}$ while figure $5 \mathrm{~b}$ shows surface plot. From figure $5 \mathrm{~b}$, the density decreased with increase in CBCS content and increased with increase in curing period. The density of the control concrete specimens increased from 2703 to $2756 \mathrm{Kg} / \mathrm{m}^{3}$. Concrete samples containing 20\% CBCS have lowest density values compared to the other mixes, with density values of 2536 and 2570 $\mathrm{Kg} / \mathrm{m}^{3}$ at the age of 7 and 60 days, respectively. These lie within the range of 2200 to $2600 \mathrm{Kg} / \mathrm{m}^{3}$ specified as the density of normal weight concrete [22].

\section{Design-Expert@ Software}

$$
\begin{aligned}
& \text { Density } \\
& \text { Design Points } \\
& \prod_{2536}^{2756}
\end{aligned}
$$

$\mathrm{X} 1=\mathrm{A}: \mathrm{CBCS}$

$\mathrm{X} 2=\mathrm{B}: \mathrm{CP}$

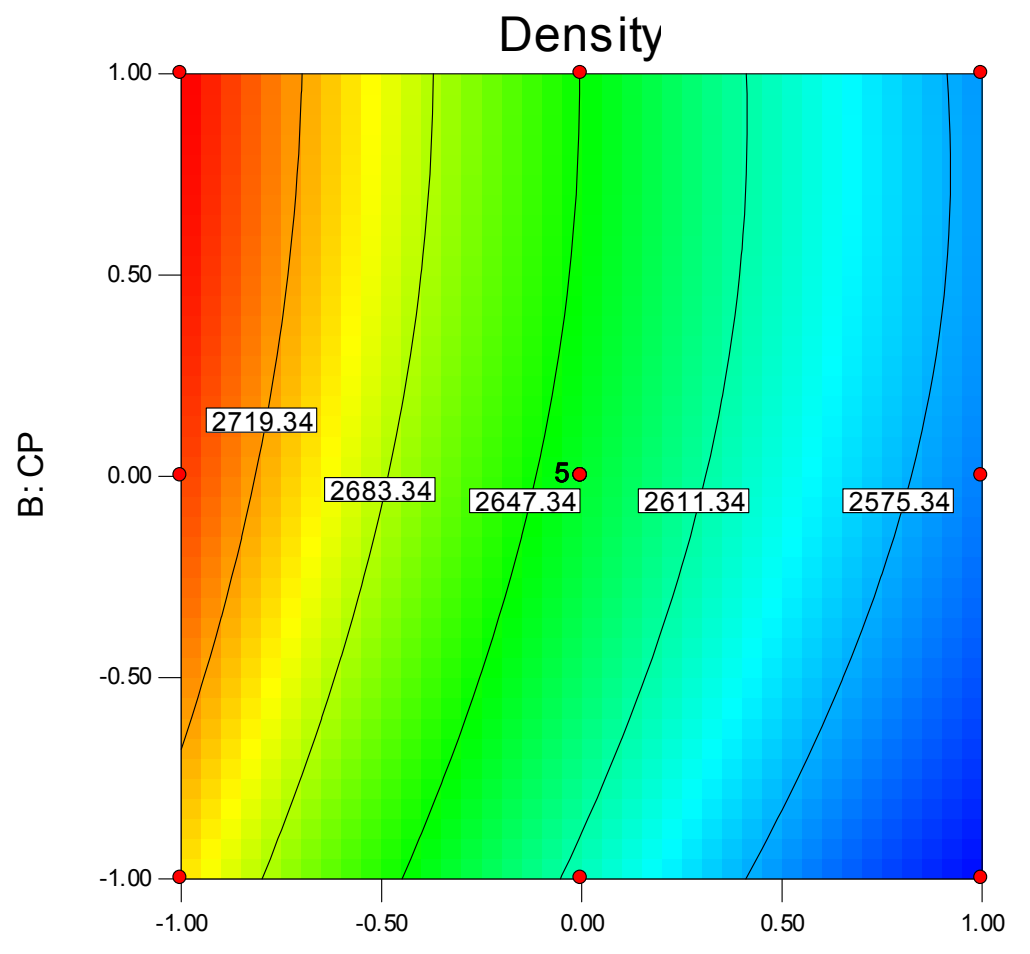

A: CBCS 


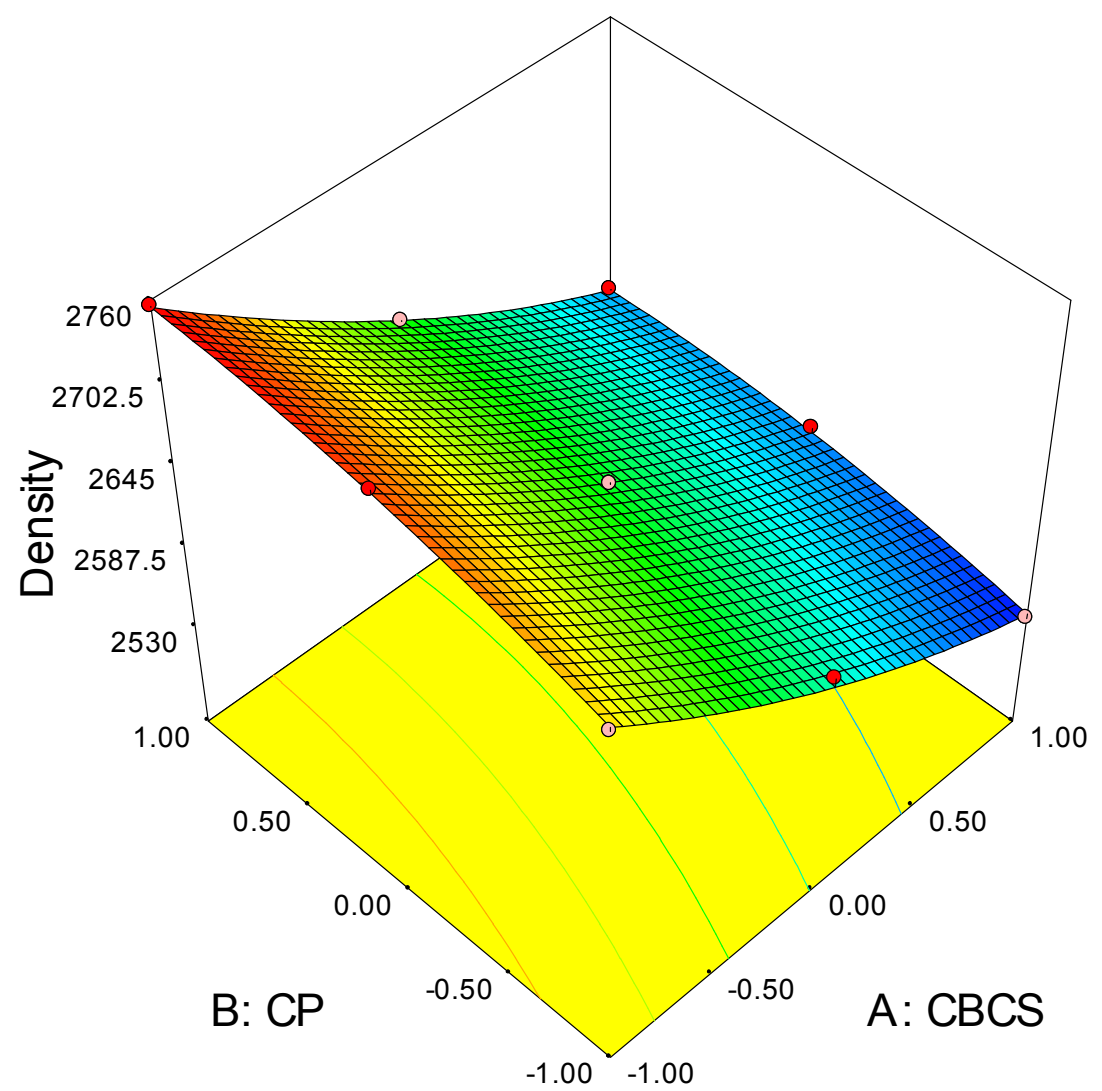

Figure 5. $(a \& b)$ Variation of Density with CBCS and Curing Period.

Table 4 shows result of ANOVA of density for various CBCS contents. The F-value of 881.59 was obtained for the model which implies the model is significant. The P-values less than 0.05 indicate that the model terms are significant. In this case $\mathrm{A}$, $\mathrm{B}, \mathrm{AB}, \mathrm{A}^{2}, \mathrm{~B}^{2}$ are significant model terms. The $\mathrm{R}^{2}$ is 0.9984 while the adjusted $\mathrm{R}^{2}$ is 0.9973 which indicate that there is excellent relationship between the predictors and the response. The model equations are presented in equations (3) \& (4).

The model equation in terms of coded factors is presented in equation (3):

$$
\text { Density }=+2637.07-88.0 * \mathrm{~A}+20.0 * \mathrm{~B}-4.75 * \mathrm{~A} * \mathrm{~B}+15.76 * \mathrm{~A}^{2}-10.24 * \mathrm{~B}^{2}
$$

The model equation in terms of actual factors is presented in equation (4):

$$
\text { Density }=+2637.06897-88.0 * \mathrm{CBCS}+20.0 * \mathrm{CP}-4.75 * \mathrm{CBCS} * \mathrm{CP}+15.75862 * \mathrm{CBCS}^{2}-10.24138 * \mathrm{CP}^{2}
$$

Table 4. ANOVA results for density.

\begin{tabular}{lllllll}
\hline Source & Sum of squares & df & Mean square & F value & p-value & Effect \\
\hline Model & 49698.15 & 5 & 9939.63 & 881.59 & $<0.0001$ & significant \\
A-CBCS & 46464.00 & 1 & 46464.00 & 4121.11 & $<0.0001$ & \\
B-CP & 2400.00 & 1 & 2400.00 & 212.87 & $<0.0001$ & \\
AB & 90.25 & 1 & 90.25 & 8.00 & 0.0254 \\
$\mathrm{~A}^{2}$ & 685.88 & 1 & 685.88 & 60.83 & 0.0001 \\
$\mathrm{~B}^{2}$ & 289.68 & 1 & 289.68 & 25.69 & 0.0014 & \\
Residual & 78.92 & 7 & 11.27 & & \\
Lack of Fit & 78.92 & 3 & 26.31 & & \\
Pure Error & 0.000 & 4 & 0.000 & & \\
Total & 49777.08 & 12 & & & & \\
\hline
\end{tabular}

\subsection{Compressive Strength}

The compressive strength test on hardened concrete cube specimens containing CBCS were carried out in accordance with BS EN 12390:4 [19]. Figure 6a shows contour plot while figure $5 \mathrm{~b}$ shows surface plot. The results show that the compressive strength increased with curing ages and decreased with increase in CBCS content. The concrete cubes with $0 \%$ CBCS had the highest rate of early strength development. At 7 days, the result showed a decrease in strength from $23.96 \mathrm{~N} / \mathrm{mm}^{2}$ at $0 \%$ CBCS content to $8.41 \mathrm{~N} / \mathrm{mm}^{2}$ at $20 \% \mathrm{CBCS}$ content. Similar trend was observed at 14 days, the compressive strength decreased 
from $23.99 \mathrm{~N} / \mathrm{mm}^{2}$ at $0 \%$ CBCS content to $11.42 \mathrm{~N} / \mathrm{mm}^{2}$ at $20 \%$ CCA content. At 28 days, there was continuous decrease in compressive strength for all the percentages of CBCS.

\section{Compressive strength}

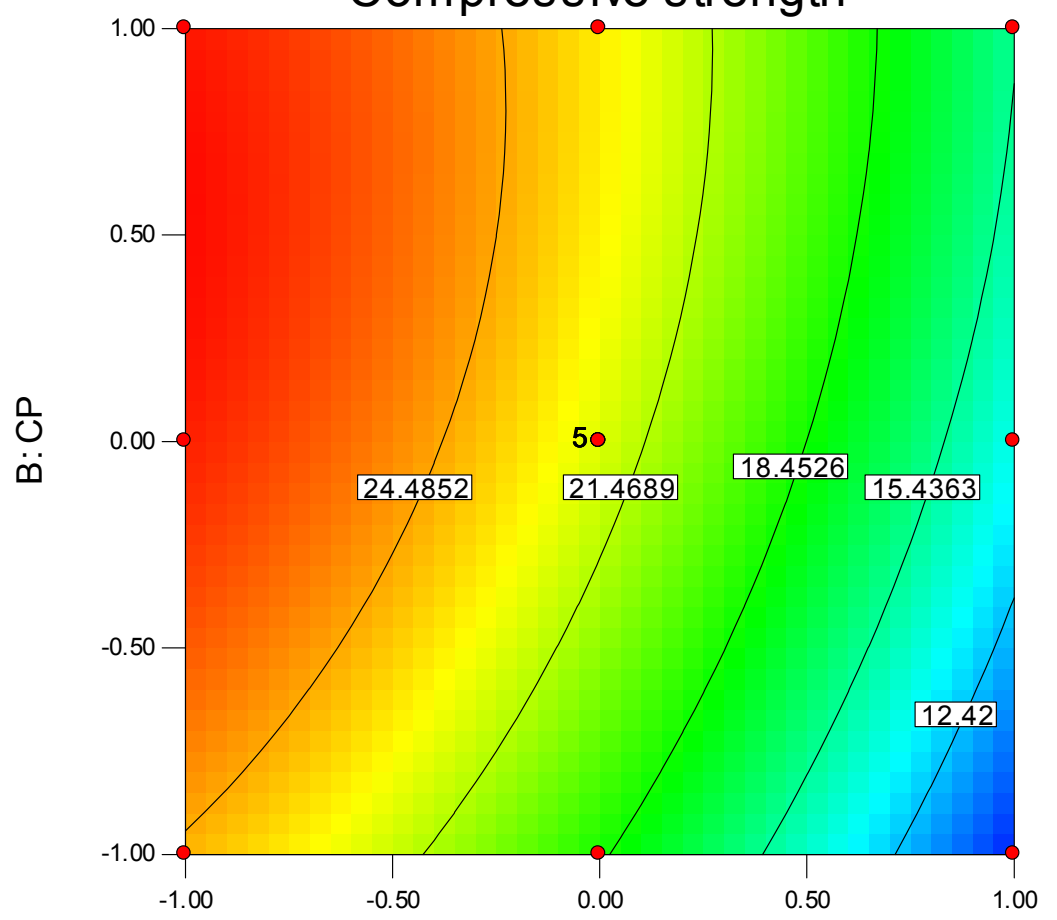

A: CBCS

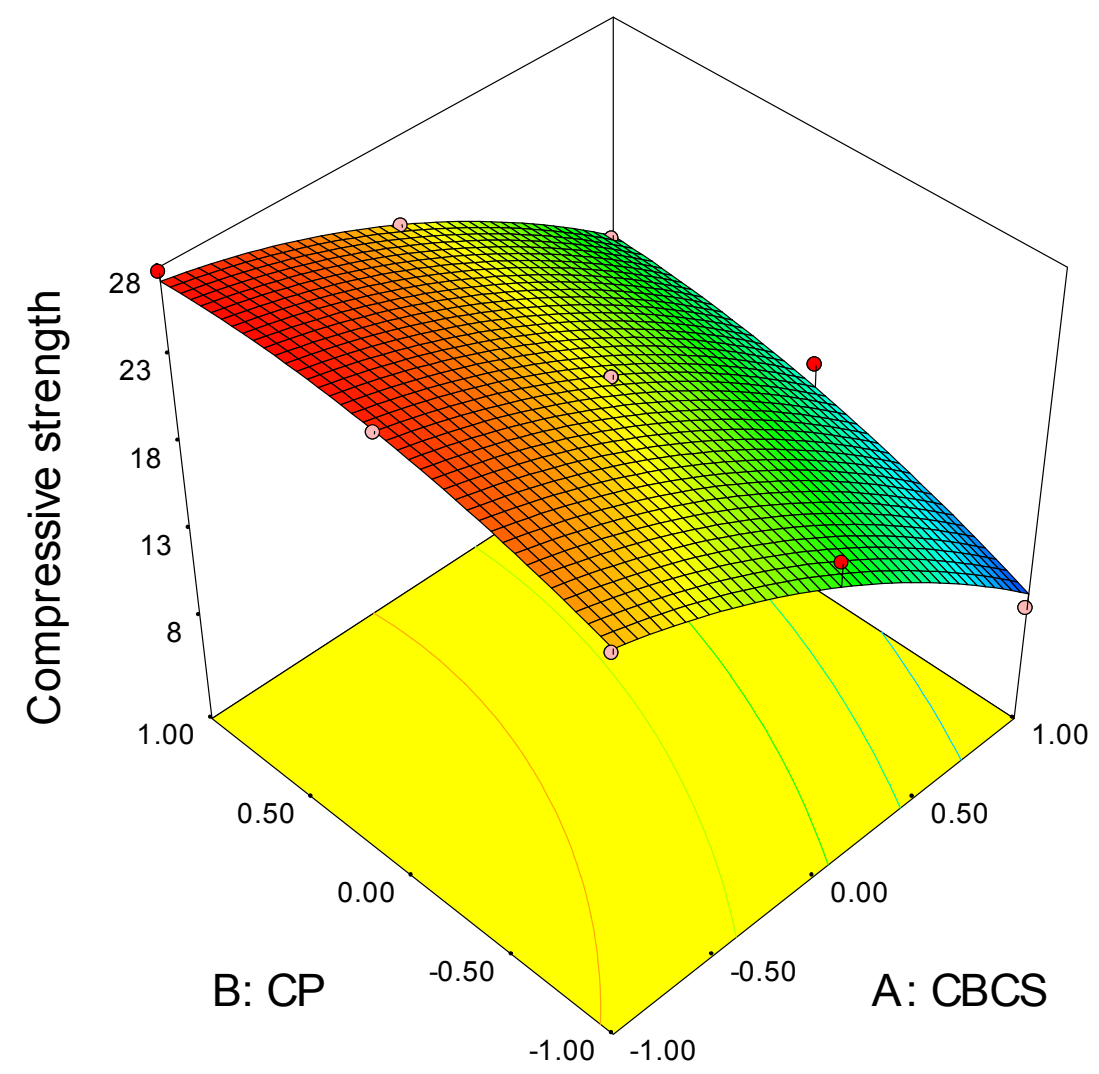

Figure 6. $(a \& b)$ Variation of Compressive Strength with CBCS and Curing Period. 
Table 5 shows result of ANOVA of density for various CBCS contents. The F-value of 91.50 obtained for the model implies that the model is significant. The P-values are less than 0.05 which indicate that the model terms are significant. In this case $\mathrm{A}, \mathrm{B}, \mathrm{A}^{2}, \mathrm{~B}^{2}$ are significant model terms. The $\mathrm{R}^{2}$ is 0.9849 while the adjusted $R^{2}$ is 0.9742 which indicate that there is excellent relationship between the predictors and the compressive strength. The model equations are presented in equations (5) \& (6).

The model equation in terms of coded factors is presented in equation (5):

$$
\text { Compressive strength }=+22.22-6.65 * \mathrm{~A}+2.28 * \mathrm{~B}+0.78 * \mathrm{~A} * \mathrm{~B}-1.80 * \mathrm{~A}^{2}-1.30 * \mathrm{~B}^{2}
$$

The model equation in terms of actual factors is presented in equation (6):

Compressive strength $=+22.21966-6.650 * \mathrm{CBCS}+2.28333 * \mathrm{CP}+0.7750 * \mathrm{CBCS} * \mathrm{CP}-1.80379 * \mathrm{CBCS}^{2}-1.30379 * \mathrm{CP}^{2}(6)$

Table 5. ANOVA results for compressive strength.

\begin{tabular}{lllllll}
\hline Source & Sum of squares & df & Mean square & F value & p-value \\
\hline Model & 320.81 & 5 & 64.16 & 91.50 & $<0.0001$ \\
A-CBCS & 265.34 & 1 & 265.34 & 378.40 & $<0.0001$ \\
B-CP & 31.28 & 1 & 31.28 & 44.61 & 0.0003 \\
AB & 2.40 & 1 & 2.40 & 3.43 & 0.1066 \\
A $^{2}$ & 8.99 & 1 & 8.99 & 6.82 & 0.0090 \\
B $^{2}$ & 4.69 & 1 & 4.69 & & 0.0361 \\
Residual & 4.91 & 7 & 0.70 & & \\
Lack of Fit & 4.91 & 3 & 0.000 & & \\
Pure Error & 0.000 & 4 & & & \\
Total & 325.72 & 12 & & & \\
\hline
\end{tabular}

Studies, 3 (6), 47-51.

\section{Conclusion}

The research examined the properties of concrete containing CBCS as partial replacement of Ordinary Portland Cement. Based on the results obtained, the following conclusions were made:

1. Calcined black cotton soil was characterized as a pozzolana.

2. The strength activity index of CBCS concrete at 28 days was greater than $75 \%$.

3. CBCS increases durability of concrete by decreasing its water absorption.

4. All the response surface models developed for water absorption, density and compressive strength showed very good relationship between the predictors and the responses with coefficients of determination, $\mathrm{R} 2>0.94$ and $\mathrm{p}$-values $<0.05$.

\section{References}

[1] Arshad, M. T. et al. (2018). Cementitious Composites Reinforced with Multiwalled Carbon Nano Tube Dispersed in Gum Arabic. International Journal of Technology and Engineering Studies. 4 (6), 227-232. doi: https://dx.doiorg/10.20469/ijtes.4.10004-6

[2] Nicoara, A. I. et al. (2020). End-of-life Materials used as Supplementary Cementitious Materials in the Concrete Industry. Materials. 13 (8). doi: 10.3390/ma13081954.

[3] Abubakar, A., Mohammed, A., \& Duna, S. (2016). Mechanical Properties of Concrete Containing Corncob Ash. International Journal of Scientific Research and Engineering
[4] Sakir, S. et al. (2020). Utilization of By-Product and Waste as Supplementary Cementitious Materials in Structural Mortar for Sustainable construction. Sustainability. 12 (9). doi: $10.3390 /$ su 12093888 .

[5] Osinubi, K. J., Eberemu, A. and Oyelakin, M. (2011). Improvement of Black Cotton Soil with Ordinary Portland Cement - Locust Bean Waste Ash Blended, Electronic Journal of Geotechnical Engineering, 16. 619-620.

[6] Myers, R. H., \& Montgomery, D. C. (2002). Response Surface Methodology: Process and Product Optimization using Desinged Experiment. A Wiley-Interscience Publication.

[7] Alejandra, T., Trezza, M. A., Scian, A. N. \& Edgardo, F. I. (2013). Assessment of Pozzolanic Activity of Different Calcined Clays, Cement and Concrete Composites. 37. 319327. 10.1016/j.cemconcomp.2013.01.002.

[8] BS EN 197. Cement - Part 1: Composition, specifications and conformity criteria for common cements. British Standard Specification, London, 1992.

[9] BS EN 1097. Tests for mechanical and physical properties of aggregates - Part 6: Determination of Particle Density and Water Absorption. British Standard Specification, London, 2000 .

[10] BS 812. Testing Aggregates - Part 2: Methods of Determination of Density, British Standard Specification, London, 1995.

[11] BS EN 933. Determination of Particle Size Distribution - Part 1: Sieving Method. British Standard Specification, London, 1997.

[12] BS 812. Testing Aggregates - Part 110: Methods for determination of aggregate crushing value (ACV). British Standard Specification, London, 1990. 
[13] ASTM C 311. (2011). Standard Test Methods for Sampling and Testing Fly Ash or Natiral Pozzolans for use in Porland Cement Concrete. Philadelphia, USA: Annual Book of ASTM Standards.

[14] ASTM C 618 (2012). Standard Specification for Fly Ash and Raw or Calcined Natural Pozzolan for use as a Mineral Admixture in Portland Cement Concrete. Philadelphia, USA: Annual Book of ASTM Standards.

[15] BS EN 12390. Testing hardened concrete - Part 1: Shape, dimensions and other requirements for specimens and moulds. British Standard Specification, London, 2000.

[16] BS EN 12390. Testing hardened concrete - Part 2: Making and curing specimens for strength tests. British Standard Specification, London, 2000.

[17] BS EN 12350. (1999). Testing of Fresh Concrete-Part 2: Slump Test. London: British Standard Specification.
[18] BS EN 12390. Testing hardened concrete - Part 3: Compressive strength of test specimens. British Standard Specification, London, 2001.

[19] BS EN 12390. Testing hardened concrete - Part 4: Compressive strength Specification for testing machines. British Standard Specification, London, 2000.

[20] BS EN 12390. Testing hardened concrete - Part 7: Density of hardened concrete. British Standard Specification, London, 2000 .

[21] BS 1881. Testing concrete - Part 122: Method for determination of water absorption. British Standard Specification, London, 1983.

[22] Neville, A. M. (2000). Properties of Concrete, 4th Edition, England, Longman. 